\title{
YALE NATURAL RADIOCARBON MEASUREMENTS VII
}

\author{
MINZE STUIVER and EDWARD S. DEEVEY
}

Geochronometric Laboratory, Yale University, New Haven, Connecticut

The following list includes many of the measurements made since publication of Yale VI, but many are withheld pending receipt of more complete information or additional samples. We report dates in terms of the Libby half life of $\mathrm{C}^{14}, 5570 \pm 30 \mathrm{yr}$; geochemical measurements, when normalized for $\mathrm{C}^{13}$ content, are given as $\Delta$ in parts per mil, as described in Yale VI. As before, we acknowledge the technical assistance of George Young, Jonathan King, Sheldon Nankin, and now Carolyn Haupt who has also joined our staff. Our work has been supported by the National Science Foundation, under grants G-19080 to Stuiver and G-19335 to Deevey, and by the U. S. Atomic Energy Commission under contract AT (30-1)-2652.

\section{SAMPLE DESCRIPTIONS}

\section{GEOLOGIC SAMPLES}

\section{Mesters Vig series, NE Greenland}

Shells (id. by H. G. Richards, Acad. Nat. Sci., Philadelphia, and by Percy Morris, Yale Univ.) and driftwood at various altitudes, many in a problematic till-like deposit in the district of Mesters Vig (72 $\mathrm{N}$ Lat, 24 ${ }^{\circ} \mathrm{W}$ Long), $\mathrm{S}$ side of Kong Oscars Fjord, NE Greenland, ca. $50 \mathrm{~km}$ from the entrance. Some samples selected from emerged marine deposits, others for comparison from problematic deposit to decide whether inclosing material was till or an uplifted fjord-bottom deposit. In addition dating of emerged deposits provides information on rate and amount of crustal uplift in the district. Coll. 1959, 1960 and subm. by A. L. Washburn, Yale Univ. Comment: samples are described and discussed by Washburn and Stuiver (1962); as there is a close relation between date and altitude, the fossiliferous till-like deposit is inferred to be an uplifted fjord-bottom deposit. The present ice-free areas have been ice free since ca. 8500 B.P. After correction of altitudes for eustatic rise of sealevel, rate of emergence during the interval 9000 to 6000 B.P. is found to have been high initially, ca. $9 \mathrm{~m}$ per century, decreasing exponentially to ca. $0.6 \mathrm{~m}$ per century. Driftwood samples near present shoreline indicate near-stability (emergence perhaps as little as $7 \mathrm{~cm}$ per century) since ca. 6000 B.P., but this interval is not well documented. Shell dates are corrected for an apparent age of $550 \pm 70 \mathrm{yr}$, that of modern shells (Y-606) from the same locality.

Y-596. Korsbjerg 59 m

$8760 \pm 250$

Mya truncata L., alt $59 \pm 2 \mathrm{~m}(84 \pm 2 \mathrm{~m}$ after correction), Korsbjerg, NE slope, at surface of stony sand (deltaic (?) bench).

Y-599. Nyhavn 66-69 m

$\mathbf{8 7 8 0} \pm \mathbf{2 5 0}$

Mya truncata L. and Hiatella arctica (L.), alt 66-69 $\pm 2 \mathrm{~m}$ (91-94 \pm 
$2 \mathrm{~m}$ after correction), Nyhavn hills, NW side of trap knob, map-summit $112 \mathrm{~m}$, at surface of till-like deposit.

Y-600. Korsbjerg 2-4 m

$6690 \pm 210$

Mya truncata L., alt 2-4 $\pm 0.5 \mathrm{~m}(8-10 \pm 0.5 \mathrm{~m}$ after correction, Korsbjerg, NE slope, cut bank of emerged delta at Noret outlet of Tunnelelv; in situ, shells with both valves, in silt.

Y-602. Labben 7-8 m

$7540 \pm 180$

Hiatella arctica (L.), alt $7-8 \pm 1 \mathrm{~m}(21-22 \pm 1 \mathrm{~m}$ after correction), Labben hills, cut bank of stream adjacent to experimental Site 5, in stony silt.

Y-606. Modern shells

$\mathbf{0} \pm \mathbf{7 0}$

Shells of living molluscs (Astarte borealis Schumacker, A. crenata Gray, Cardium ciliatum Fabricius, Hiatella arctica (L.), Margarites undulata Sowerby, Mya arenaria L. (?), M. truncata L.) dredged at -2 to $-15 \mathrm{~m}$ (estimated), Nyhavn, S cove. Apparent age $550 \pm 70$, referred to NBS oxalicacid standard; taken as $0 \pm 70$ in calculating other shell dates in the district.

Y-702. Korsbjerg $3 \mathrm{~m}$, driftwood

$735 \pm 110$

Driftwood, alt $3 \pm 0.5 \mathrm{~m}$ (not corrected), Korsbjerg, NE slope, inner edge of emerged strandline on delta at Noret outlet of Tunnelelv.

Y-703. Korsbjerg $4 \mathrm{~m}$, driftwood

$2980 \pm 120$

Driftwood at same locality as Y.702, but at inner edge of another emerged strandline $1 \mathrm{~m}$ above Y-702.

Y-704. Labben $31 \mathrm{~m}$

$7730 \pm 210$

Mya truncata L., alt $31 \pm 2 \mathrm{~m}(47 \pm 2 \mathrm{~m}$ after correction), Labben hills, adjacent to experimental Site 3 . Shell fragments abundant, in clayey silt containing stones, now patterned ground.

Y-708. Nyhavn 16-20 m

$6670 \pm 250$

Mytilus edulis L., alt $16-20 \pm 1 \mathrm{~m}(22-26 \pm 1 \mathrm{~m}$ after correction), Nyhavn hills, at surface, cut in deltaic beds at SW base of trap knob, map. summit $78 \mathrm{~m}$.

Y-711. Danevirke 67-76 m $\quad 8500 \pm 250$

Hiatella arctica (L.) and Mya truncata L., alt 67.76 $\pm 2 \mathrm{~m}$ (90-99 \pm $2 \mathrm{~m}$ after correction), Danevirke hills, at surface of sand, cut in deltaic beds $1 / 2 \mathrm{~km} \mathrm{SE}$ of trap knob, map-summit $125 \mathrm{~m}$.

Y-712. Blyryggen $45-52 \mathrm{~m}$

$8480 \pm 140$

Mya truncata L., alt $45-52 \pm 2 \mathrm{~m}(67-74 \pm 2 \mathrm{~m}$ after correction), Blyryggen, SE slope, cut bank of emerged delta, SW side Holberg Elv. At surface of stony sand, some shells with both valves.

Y-713. Blyryggen 52-57 m

$8360 \pm 140$

Mya truncata L., alt 52-57 $\pm 2 \mathrm{~m}$ (73-78 $\pm 2 \mathrm{~m}$ after correction), same locality as Y-712, upper limit $3 \mathrm{~m}$ below delta tread. 
Y-714. Blyryggen $7-10 \mathrm{~m}$

Hiatella arctica (L.), Mya truncata L., and Serripes groenlandica Bruguière, alt 7-10 $\pm 1 \mathrm{~m}(15-18 \pm 1 \mathrm{~m}$ after correction), Blyryggen, $\mathrm{SE}$ slope, cut bank of bench on which Expeditionshus is located. At surface of stony sand and silt.

Y-716. Danevirke 67.76 m

$8780 \pm 210$

Hiatella arctica (L.) and Mya truncata L., same locality and collection as Y.711, but an independent check.

Y-717. Nyhavn 16-20 m

$6650 \pm 200$

Mya truncata L., same locality as Y-708, at surface.

Y-876. Hesteskoen $29 \mathrm{~m}$

$8000 \pm 160$

Hiatella arctica (L.) and Mya truncata L., alt $29 \pm 2 \mathrm{~m}(47 \pm 2 \mathrm{~m}$ after correction), Hesteskoen, NE slope, cut bank in deltaic beds at $\mathrm{E}$ base of trap knob, map-summit $90 \mathrm{~m}$. In situ in sand, shells with both valves.

Y-878. Hesteskoen 19-20 m

$6950 \pm 150$

Hiatella arctica (L.) and Mya truncata L., alt 19-20 $\pm 1 \mathrm{~m}$ (20-29 after correction), Hesteskoen, NE slope, cut bank at $\mathrm{N}$ tip of second delta sector NW of Tunnelelv. In situ in sand, shells with both valves.

Y-879. Hesteskoen $20 \mathrm{~m}$, driftwood

$7460 \pm 130$

Driftwood, same locality as Y-878, at surface.

Y-882. Blyryggen $14 \mathrm{~m}$, driftwood

$5590 \pm 140$

Driftwood, alt $4 \pm 0.5 \mathrm{~m}$ (not corrected), Blyryggen, SE slope, channel of 1 V Elv. Partly in till-like deposit.

Y-883. Blyryggen 3-4 m

$6840 \pm 210$

Astarte borealis Schumacker, Clinocardium ciliatum Fabricius, Hiatella arctica (L.), Mya truncata L., and Mytilus edulis L., alt 3-4 $\pm 0.5 \mathrm{~m}$ (11-12 $\pm 0.5 \mathrm{~m}$ after correction), same locality as Y-882. At surface of till-like deposit.

Y-884. Blyryggen 1-3 m

$4960 \pm 320$

Astarte borealis Schumacker, alt 1-3 $\pm 0.5 \mathrm{~m}$ (not corrected), Blyryggen, SE slope, cut bank by first small stream SW of $1 \mathrm{~V}$ Elv. In situ in sand, shells with both valves.

\section{San Augustin Plains series, New Mexico}

Calcareous and organic material from silty lacustrine clay in Core BHM, $50 \mathrm{ft}$ long, surface alt $6775 \mathrm{ft}$ above sealevel, San Augustin Plains $\left(33^{\circ} 50^{\prime} \mathrm{N}\right.$ Lat, $108^{\circ} 10^{\prime} \mathrm{W}$ Long), Catron County, New Mexico. Modern playa occupies ca. $35 \mathrm{mi}^{2}$ at $\mathrm{W}$ end of Plains; during late Pleistocene, the ancestral lake covered a maximum area of $255 \mathrm{mi}^{2}$ in interior drainage basin of ca. 2000 $\mathrm{mi}^{2}$. Other cores, one reaching depth of $2000 \mathrm{ft}$, are being analyzed for pollen 
and mineralogy (Clisby and Foreman, 1958) ; the short Core BHM, taken primarily for $\mathrm{C}^{14}$ dating, is correlated with the upper part of the longer cores by pollen and lithologic zones, and its pollen diagram has been published by Clisby, Foreman, and Sears (in press). Subm. 1961 by K. H. Clisby, Oberlin College, Ohio.

Y-1050. San Augustin BHM 4-5 ft

$12,170 \pm 260$

Carbonate from 4 to $5 \mathrm{ft}$ depth, at top of high-spruce-pollen zone and just below disturbed sediments of modern playa.

Y-1050B. San Augustin BHM 4-5 ft, organic $\quad 11,445 \pm 230$ Organic matter from sample Y-1050.

Y-1051. San Augustin BHM 8-9 ft

$12,130 \pm 290$

Carbonate from 8 to $9 \mathrm{ft}$ depth, in zone of high but variable spruce pollen, including last spruce maximum. Comment: not significantly different from Y-1050 or Y-1050B. The last spruce maximum appears to be of approximately Port Huron age.

\section{Y-1052. San Augustin BHM 12-13 ft}

$17,650 \pm 350$

Carbonate from 12 to $13 \mathrm{ft}$ depth, in zone of minimum spruce and maximum pine pollen, with significant traces of NAP; interpreted as a cool-climate zone, but slightly warmer than dated zones above and below.

Y-1052B. San Augustin BHM 12-13 ft, organic $16,885 \pm 630$

Organic matter from sample Y-1052. Comment: not significantly different from Y-1052, the carbonate fraction.

Y-1053. San Augustin BHM 19-20 ft

$23,070 \pm 650$

Carbonate from 19 to $20 \mathrm{ft}$ depth, in zone of high spruce pollen, including third-from-last spruce maximum and minimum of pine; a deep minimum of spruce lies slightly lower, at $23.5 \mathrm{ft}$, but abundant NAP, characteristic of most of the long Core BHK, is encountered only below $30 \mathrm{ft}$ in this core. Dated zone is interpreted as cold and wet, following a slightly warmer but still wet phase. Comment: date suggests that the spruce minimum at $23.5 \mathrm{ft}$, and/or the layer of more friable silt that extends from 23 to $32.5 \mathrm{ft}$ (below the homogeneous lacustrine clay from which all the dated samples came), are equivalent to the Lower Salt body in Searles Lake, California (Flint and Gale, 1958) ; relatively large amounts of spruce pollen, and lack of evidence for desiccation, are not unexpected in view of the considerably greater altitude of the San Augustin Plains.

\section{Hackberry Lake series, Nebraska}

Gyttja from core, $4.8 \mathrm{~m}$ long, under $1 \mathrm{~m}$ of water, overlying blue sand, in Hackberry Lake, T $30 \mathrm{~N}, \mathrm{R} 29 \mathrm{~W}\left(42^{\circ} 35^{\prime} \mathrm{N}\right.$ Lat, $100^{\circ} 40^{\prime} \mathrm{W}$ Long), alt $2923 \mathrm{ft}$ above sealevel, Valentine Natl. Wildlife Refuge, in the Nebraska Sandhills. Pollen stratigraphy has been published by Sears (1961). Coll. 1959 by W. N. Irving, L. G. Madison, and P. B. Sears; subm. by Sears, Yale Univ. 
Y-911. Hackberry $1.5 \mathrm{~m}$

$1110 \pm 75$

From $1.5 \mathrm{~m}$ below sediment surface, overlying zone rich in grass and prairie-herb pollen, interpreted as equivalent to the oak-hickory zone (C-2) of eastern U. S. Comment: date is too late for beginning of Zone C-3, but the several maxima of grass and herb pollen are probably related to cultural changes, and climatic interpretations may be premature.

Y.912. Hackberry $4.5 \mathrm{~m}$

$\mathbf{5 9 4 0} \pm \mathbf{9 5}$

From $4.5 \mathrm{~m}$ below sediment surface, below the zones believed to be equivalent to $\mathrm{C}$-2, in zone relatively rich in arboreal pollen, interpreted as cooler and moister than the present. Comment: date is reasonable for the top of Zone C-1 (oak-hemlock, i.e. a moist phase) in eastern U. S., or for bottom of Zone C-2. Sampled level is near the beginning of lacustrine deposition; formation of the basin, part of dune-and-pan topography, may perhaps be assigned to a drier phase, the beginning of the postglacial xerothermic interval. Sears (1961) noted the similarity in age and climatic interpretation between dated level and the Michillinda peat bed exposed on the shore of Lake Michigan (Sears and Bopp, 1960).

\section{Y-1097. El Bajo de Santa Fé, Guatemala $\quad 11,560 \pm 360$}

Carbonaceous material from $511 \mathrm{~cm}$ depth in a pit, excavated in El Bajo de Santa Fé, a swampy area at Tikal (17 $14^{\prime} \mathrm{N}$ Lat, $89^{\circ} 38^{\prime} \mathrm{W}$ Long), department of El Petén, Guatemala. Material is non-cellular, of problematic origin, occurring mixed with clay and gypsum from sampled level to an unknown depth below bottom of pit; overlying clay was thought initially to be lacustrine. Coll. 1959 by Ursula Cowgill; subm. by her and G. E. Hutchinson, Yale Univ. Comment (G.E.H.) : indicates rate of sedimentation in a swamp deposit, which will be the subject of a complete geochemical study in the near future. The sediment is certainly not lacustrine and is inconsistent with the hypothesis that a large body of open water existed in the vicinity in Maya times.

\section{Lago di Monterosi series, Italy}

Additional gyttja samples from cores under $5 \mathrm{~m}$ of water, Lago di Monterosi $\left(42^{\circ} 12^{\prime} \mathrm{N}\right.$ Lat, $12^{\circ} 18^{\prime} \mathrm{E}$ Long), from which five dates were reported in Yale VI. Coll. 1959 by Enrico Bonatti and W. T. Edmondson; subm. by G. E. Hutchinson and Ursula Cowgill.

Y-967. Monterosi M-I, 212-227 cm

$17,040 \pm 350$

Above bottom of Core M-I, the bottom of which, from 244 to to $248 \mathrm{~cm}$, was dated at 24,460 \pm 1300 (Y-974, Yale VI).

Y-968. Monterosi M-I, 192-207 cm

$10,920 \pm 210$

Above Y.967.

Y-970. Monterosi M-I, $157-172 \mathrm{~cm}$

$\mathbf{3 0 3 7} \pm \mathbf{7 0}$

Above Y-968, below Y-913, 128 to $148 \mathrm{~cm}$, dated at $1573 \pm 77$ (Yale VI). Comment: these three additional samples, taken below the maximum of 
organic matter, confirm the very slow rate of sedimentation during the early (pre-Roman) oligotrophic phase of the lake.

Y-976. Monterosi M-II, $102-133 \mathrm{~cm}$

$2220 \pm 120$

From core M-II, not analyzed for pollen, but extensively analyzed for chemistry and mineralogy; sample includes the zone of maximum organic $\mathrm{N}$, the upper part of which was dated, in Core M-I, at $1573 \pm 77$ (Y-913, Yale VI). Comment: confirms the belief that eutrophication of the lake took place in Roman Republican time, when Via Cassia or a precursor road was constructed.

Lake Zeribar, Iran

$5460 \pm 120$

Calcareous gyttja, 9.90 to $10.10 \mathrm{~m}$ depth in core (Zeribar II, Iran 13) under marsh at edge of Lake Zeribar, $35^{\circ} 31^{\prime} \mathrm{N}$ Lat, $46^{\circ} 07^{\prime} \mathrm{E}$ Long), ca. $160 \mathrm{~km} \mathrm{NW}$ of Kermanshah, Zagros Mountains, Iran. Unpublished pollen diagrams of this and another core, by Willem Van Zeist, indicate three major pollen zones: A, dominantly chenopodiaceous, probably treeless; $\mathrm{B}$, arboreal pollen dominantly pistacio and oak, with much chenopod pollen, probably a park landscape; C, high-oak, low-NAP zone, probably a fairly closed woodland like today's. Sample is from bottom of Zone C, here ca. $8 \mathrm{~m}$ thick and interrupted only once, at ca. $5 \mathrm{~m}$ depth, by an NAP maximum of probable cultural origin. Coll. 1960, as part of Oriental Inst. expedition, by H. E. Wright, Jr., and associates; subm. by Wright, Univ. of Minnesota. Comment: dates the end of a period (that of Zone B) that is believed to have been markedly drier than the present, formerly suspected to be Pleistocene, but seen, in light of the date, to have terminated much later.

\section{ARCHAEOLOGIC SAMPLES}

\section{Y-981. Hunter site, New York}

$2802 \pm 70$

Charcoal, remnant of a crematory fire, including fragments of leather shroud, reburied in Burial 1, 25 to 30 in. below surface, accompanied by diagnostic Point Peninsula artifacts, Hunter site on Red Lake, Theresa $\left(44^{\circ}\right.$ $16^{\prime} 24^{\prime \prime} \mathrm{N}$ Lat, $75^{\circ} 44^{\prime} \mathrm{W}$ Long), Jefferson County, New York. Portion of sample dated as C-794 (Chicago IV). Coll. and subm. by W. A. Ritchie, N. Y. State Mus., Albany. Comment: Chicago date was $4400 \pm 260$ (C-794, Chicago IV); the new determination is considered much more acceptable as a date for classic Point Peninsula.

\section{Brooks River series, Alaska}

Charcoal and peat from stratified archaeologic site on Brooks River $\left(58^{\circ} 40^{\prime} \mathrm{N}\right.$ Lat, $155^{\circ} 44^{\prime} \mathrm{W}$ Long), Katmai Natl. Monument, Alaska. Occupation layers partly separated by volcanic ash layers. Coll. and subm. 1960 by L. S. Cressman, Univ. of Oregon, Eugene.

\section{Y-930. Brooks River 1}

$3972 \pm 440$

Small sample of charcoal, Sample no. 1 (BR3, L10), from oldest occupation, directly above glacial gravel, accompanied by microliths. 
Y-931. Brooks River 2

$3860 \pm 90$

Peat, $120 \mathrm{~cm}$ below surface, Sample no. 2, immediately underlying volcanic ash layer.

Y-932. Brooks River 3

$450 \pm 60$

Charcoal, Sample no. 3 (LB, F18), from occupation immediately above volcanic ash layer of unknown (i.e. pre-A.D. 1912) date.

\section{Y-616. Yaúnchu site, Ecuador}

$920 \pm 160$

Charcoal from Test Square A, 225 to $235 \mathrm{~cm}$ depth, Yaúnchu site $\left(2^{\circ} 28^{\prime}\right.$ $\mathrm{S}$ Lat, $78^{\circ} 10^{\prime} \mathrm{W}$ Long), Río Upano valley, lowland eastern Ecuador. Level from which sample was taken, as well as the deposit above it, contained potsherds, including Red Banded Incised type (id. by Donald Collier), described by Collier and Murra (1943, p. 61-62). Coll. 1957; subm. 1958 by M. J. Harner, Univ. of California, Berkeley.

\section{Y-617. Ipíamais site, Ecuador}

$2570 \pm 440$

Charcoal from Test Square A, 40 to $80 \mathrm{~cm}$ depth, Ipíamais site $\left(2^{\circ} 34^{\prime} \mathrm{S}\right.$ Lat, $78^{\circ} 10^{\prime} \mathrm{W}$ Long), Río Upano valley, lowland eastern Ecuador. Sampled level and overlying deposit contained potsherds, including Tuncahuán ware (id. by Clifford Evans and Betty Meggers). Coll. 1957; subm. 1958 by M. J. Harner.

\section{GEOCHEMICAL SAMPLES}

\section{A. Natural carbon monoxide}

Pandow, Mackay, and Wolfgang (1960) found that neutron irradiation of $\mathrm{N}_{2}-\mathrm{O}_{2}$ mixtures gave $\mathrm{C}^{14} \mathrm{O}$, not $\mathrm{C}^{14} \mathrm{O}_{2}$, and concluded that $\mathrm{CO}$ is more resistant to oxidation under atmospheric conditions than was assumed by Libby in his fundamental work on the origin and fate of natural radiocarbon. More recently, Wolfgang (private communication) has found a small amount of radioactive $\mathrm{CO}_{2}$ in such experiments, but still considers the main radioactive product to be CO. Dorn et al. (University of Washington I) have begun work on the problem, and present evidence for a mechanism of oxidation not considered by Pandow, MacKay, and Wolfgang. Meanwhile, in collaboration with Richard Wolfgang, Yale Univ., we have made an attempt to measure the activity of naturally occurring $\mathrm{CO}$.

The following three samples, collected by L. C. Matsch, Linde Air Products Co., Tonawanda, New York, were submitted by Wolfgang in the hope that they would be free of urban influence and so test the theory, which predicts that $\mathrm{CO}$ should have more $\mathrm{C}^{14}$ than $\mathrm{CO}_{2}$ in nature. The results are inconclusive, as less-than-normal $\mathrm{C}^{14}$ contents strongly indicate contamination by industrial CO. The samples were received as $\mathrm{BaCO}_{3}$, and were extremely small ( 70 to $200 \mathrm{mg}$ of $\mathrm{C}$ ), so that statistical errors are large. Values are reported as $\delta \mathrm{C}^{14}$ in per cent, not corrected for isotopic fraction. 
YALE NO. DESCRIPTION

$$
\begin{gathered}
\delta \mathrm{C}^{14}, \% \\
+9.3 \pm \mathbf{7 . 8}
\end{gathered}
$$

Collection dates January 21 to January 28, 1960.

\section{Y-985. Tonawanda CO}

Collection dates January 30 to February 9, 1960.

\section{Y-986. Tonawanda CO}

\section{B. Atmospheric carbon in Guatemala}

Samples of terrestrial vegetation were collected at Tikal $\left(17^{\circ} 14^{\prime} \mathrm{N}\right.$ Lat, $89^{\circ} 38^{\prime} \mathrm{W}$ Long), and near Flores ( $16^{\circ} 56^{\prime} \mathrm{N}$ Lat, $89^{\circ} 55^{\prime} \mathrm{W}$ Long), in the department of El Petén, Guatemala, in an effort to measure the specific $\mathrm{C}^{14}$ activity of the atmospheric, at this tropical rainforest locality, from before A.D. 1954, when the magnitude of the Suess effect could be estimated, through 1960, during and after the peak of artificial $\mathrm{C}^{14}$ in the atmosphere. Single tree rings being notoriously difficult to obtain, we hoped that palm thatching, used a few weeks after growth in known years, might provide a series comparable to the annual series of crop plants used by other laboratories (Tauber, 1962; Cambridge IV). In this hope we were disappointed; thatch used for buildings on the archaeologic zone of Tikal, though fully documented as to date of use by the records kept by E. M. Shook, Field Director of the Tikal Proj., appears to have undergone curing for many months after cutting and before it was used for roofing.

At any rate, this is the most reasonable interpretation of the data given below, and in Fig. 1. Y-783, a reliable sample of palm grown and used in 1953 by the Nazarene Mission at Sta. Elena, near Flores, provides an acceptable baseline, and gives a direct measure of the Suess effect (25\%o depletion), resulting from industrial $\mathrm{CO}_{2}$ in this notably nonindustrial region. Reliable samples of a few weeks' age (Y-787, maize grown near Flores in April and May, 1959; and Y-1009, new tree leaves cut at Tikal in March 1961) fall precisely on the average curve for localities in the $\mathrm{N}$ Hemisphere (Broecker and Olson, 1960), as if there were no appreciable lag in the atmospheric exchange of $\mathrm{C}^{14}$ between middle and low northern latitudes. The seven dated thatch samples from Tikal, however, are all depleted in $\mathrm{C}^{14}$, by amounts that exceed any possible lag effect. Six of them fall in line at once if one assumes a delay of 2 yr between growth and use; the seventh, Y-1023, may have been stored for 3 yr. This may seem unlikely, but Y-1023 is directly checked by Y-1009, and its relative depletion (by 9\%) is very difficult to explain on any other basis. All seven samples of course agree better with the S Hemisphere data of Broecker and Olson, in which a genuine lag effect is demonstrated, but uncertainty as to date of growth rules out these thatch samples from further consideration. 


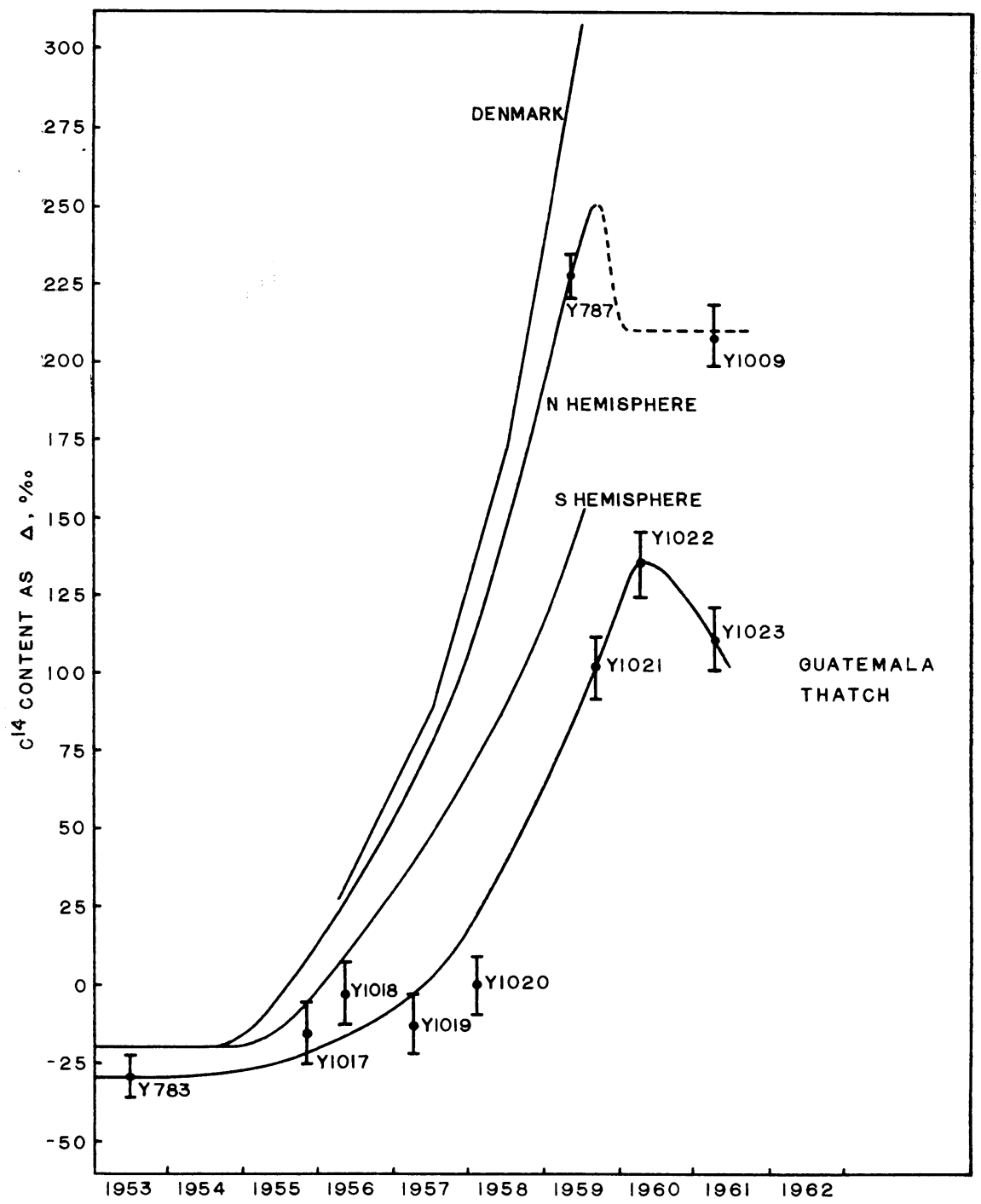

Fig. 1. $\mathrm{C}^{14}$ content, normalized for isotopic fractionation, of terrestrial vegetation at Tikal and near Flores, department of El Petén, Guatemala, 1953-1961. Curves drawn are averages of data from Denmark (Tauber, 1962), and from various stations in the $\mathrm{N}$ and $S$ Hemispheres (Broecker and Olson, 1960). Height of lines represents $1 \sigma$ on either side of the mean assay; sample descriptions are in the text.
YALE NO.
DESCRIPTION
$\delta \mathrm{C}^{14} \%$
$\Delta, \%$

Y-783. Sta. Elena thatch $1953 \quad-33.9 \pm 7 \quad-29.6 \quad-25.0 \pm 7$

From privy back of Nazarene

Mission, grown and cut 1953 by N. J.

Storey; coll. May 23, 1959 by George and Ursula Cowgill. 
$\begin{array}{llll}\text { YALE NO. DESCRIPTION } & \delta \mathrm{C}^{14}, \% 0 & \delta \mathrm{C}^{13}, \% 0 & \Delta, \% o\end{array}$

Y-787. San Andres maize 1959

$$
+261.2 \pm 7 \quad-10.2+223.9 \pm 7
$$

Grown April 26 to May 26, 1959, at San Andres, W end of Lake Petén, near Flores; coll. by George and Ursula Cowgill.

Y-1009. Tikal leaves $1961+208.1 \pm 10-29.9+219.0 \pm 10$

From tree, $4 \mathrm{~m}$ high, at Aguada

Naranja, Tikal; coll. March 9, 1961

by E. S. Deevey.

Y-1017. Tikal thatch 1955
Used, and said to have been cut, $-23.5 \pm 10-29.8-14.1 \pm 10$

November 1955; coll. 1961 by E. S. Deevey.

\section{Y-1018. Tikal thatch $1956 \quad-11.4 \pm 10(-29.7) \quad-2.1 \pm 10$}

Used, and said to have been cut, April 1956; coll. 1961 by E. S. Deevey. $\mathrm{C}^{13}$ analysis assumes average value of five thatch samples.

\section{Y-1019. Tikal thatch 1957}

Used, and said to have been cut, March 1957; coll. 1961 by E. S. Deevey.

\section{Y-1020. Tikal thatch 1958 \\ Used, and said to have been cut,}

$$
-7.8 \pm 10-29.8+1.5 \pm 10
$$
January 1958; coll. 1961 by E. S. Deevey.

\section{Y-1021. Tikal thatch 1959}

$$
+89.4 \pm 10-31.2+102.9 \pm 10
$$

Used, and said to have been cut, August 1959; coll. 1961 by E. S. Deevey.

Y-1022. Tikal thatch $1960+125.5 \pm 10(-29.7)+136.1 \pm 10$

Used, and said to have been cut, March 1960; coll. 1961 by E. S. Deevey. $\mathrm{C}^{13}$ analysis assumes average value of 5 thatch samples.

Y-1023. Tikal thateh $1961+102.8 \pm 10-28.8+111.2 \pm 10$

Used, and said to have been cut, March 1961; coll. 1961 by E. S. Deevey. 


$$
\text { C. Lake samples }
$$

The following list, mainly from Linsley Pond $\left(41^{\circ} 19^{\prime} \mathrm{N}\right.$ Lat, $72^{\circ} 47^{\prime} \mathrm{W}$ Long), North Branford, Connecticut, nearly completes the limnologic studies reported in Yale VI (and by Deevey, Stuiver, and Nakai, in press), and a paper on the carbon cycle of small lakes is in preparation by Stuiver and Deevey. Resumption of nuclear testing makes it almost impossible to continue this work.

YALE NO. DESCRIPTION $\quad \delta \mathrm{C}^{14}, \% 0 \quad \delta \mathrm{C}^{13}, \% 0 \quad \Delta, \%$

Y-1049. Linsley surface April 1961

Surface water; coll. April 21,

$$
-0.2 \pm 8 \quad-2.3 \quad-45.2 \pm 8
$$

1961 by E. S. Deevey.

Y-1061. Linsley plankton $1961-45.5 \pm 12-42.0 \quad-13.4 \pm 12$

Asterionella plankton; coll. by townet, April 15-17, 1961, by E. S. Deevey.

\section{Y-1062. Linsley surface June 1961}

Surface water; coll. June 29, 1961

$$
+62.5 \pm 10-8.8+28.1 \pm 10
$$
by J. A. King.

\section{Y-1063. Linsley deep June 1961}

$$
-48.2 \pm 10-13.6 \quad-69.9 \pm 10
$$

Water from $12.5 \mathrm{~m}$ depth; coll.

June 29, 1961 by J. A. King.

\section{Y-1064. Linsley pondweeds June 1961}

Potamogeton sp.; coll. June 29,

$$
+41.4 \pm 8 \quad-19.3 \quad+29.5 \pm 8
$$

1961 by J. A. King.

\section{Y-1065. Linsley Nuphar June 1961}

$$
+218.4 \pm 10-22.4 \quad+212.1 \pm 10
$$

Nuphar sp. (yellow water lily), leaves; coll. June 29, 1961 by J. A.

King.

\section{Y-1078. Linsley pondweeds September 1961}

$$
+63.8 \pm 10-18.5 \quad+50.0 \pm 10
$$

Potamogeton sp., coll. near middle of lake, September 6, 1961, five days after resumption of nuclear testing, by J. A. King. 
YALE NO. DESCRIPTION

$\delta \mathrm{C}^{14}, \% \circ \quad \delta \mathrm{C}^{13}, \%$

$\Delta, \%$

Y-1079. Linsley inlet pondweeds 1961

$$
+60.7 \pm 10-17.9 \quad+45.6 \pm 10
$$

Potamogeton sp., directly off inlet on N shore; coll. September 6, 1961 by J. A. King.

Y-1088. Linsley inlet $1961+19.9 \pm 10-10.6 \quad-10.5 \pm 10$

$\mathrm{N}$ inlet water; coll. August 10, 1961 by E. S. Deevey.

Y-1089. Linsley outlet $1961+120.5 \pm 10-12.2+92.0 \pm 10$

Outlet water, $50 \mathrm{~m}$ below lake;

coll. August 10, 1961 by E. S. Deevey.

\section{Y-1098. Linsley surface September 1961}

$$
+52.6 \pm 10-9.2 \quad+19.3 \pm 10
$$

Surface water; coll. September 29, 1961 by E. S. Deevey.

\section{Y-1099. Linsley deep September 1961}

Water from $13 \mathrm{~m}$ depth; coll.

$$
\mathbf{- 3 4 . 5} \pm 10-\mathbf{- 1 4 . 0} \quad-\mathbf{5 5 . 7} \pm 10
$$

September 29, 1961 by E. S. Deevey.

Y-1107. Linsley well $1961 \quad-66.4 \pm 10-13.7 \quad-87.5 \pm 10$

Water from well on $\mathrm{N}$ shore; coll. November 22, 1961 by E. S. Deevey.

Y-1069. Wononscopomuc pondweeds 1961

$$
+12.0 \pm 10-11.2 \quad-15.9 \pm 10
$$

Myriophyllum sp., organic car-

bon, Wononscopomuc Lake $\left(41^{\circ} 57^{\prime}\right.$

$\mathrm{N}$ Lat, $73^{\circ} 27^{\prime} \mathrm{W}$ Long), Salisbury, Conn.; coll. July 31, 1961 by E. S.

Deevey.

Date lists:

Cambridge IV Godwin and Willis, 1961

Chicago IV Libby, 1954

University of Washington I Dorn et al., 1962

Yale VI $\quad$ Stuiver and Deevey, 1961

Broecker, W. S., and Olson, E. A., 1960, Radiocarbon from nuclear tests II: Science, v. 132, p. 712-721

Clisby, K. H., and Foreman, 1958, Pleistocene climatic changes in New Mexico, USA: Geobot. Inst. Rübel, Zürich, Veröffentl., no. 34, p. 21-26.

Clisby, K. H., Foreman, Fred, and Sears, P. B., in press, Palynology-diastrophism-erosion: Internat. INQUA Congress, 6th, Warsaw 1961, Proc.

Collier, Donald, and Murra, J. V., 1943, Survey and excavations in southern Ecuador: Field Mus. Nat. History, Anthropol. Ser., v. 35.

Deevey, E. S., Stuiver, Minze, and Nakai, Noboyuki, in press, Use of light nuclides in limnology: Conf. Radioecology, 1st, Fort Collins, Colorado 1961, Proc. 
Dorn, T. F., Fairhall, A. W., Schell, W. R., and Takashima, Y., 1962, Radiocarbon dating at the University of Washington I: Radiocarbon, v. 4, p. 1-12.

Flint, R .F., and Gale, W. A., 1958, Stratigraphy and radiocarbon dates at Searles Lake, California: Am. Jour. Sci., v. 256, p. 689-714.

Godwin, Harry, and Willis, E. H., 1961, Cambridge University natural radiocarbon measurements IV: Radiocarbon, v. 3, p. 77-80

Libby, W. F., 1954, Chicago radiocarbon dates, IV: Science, v. 119, p. 135-140.

Pandow, M., MacKay, C., and Wolfgang, Richard, 1960, The reaction of atomic carbon with oxygen: significance for the natural radiocarbon cycle: Jour. Inorg. Nuclear Chemistry, v. 14, p. 153-158.

Sears, P. B., 1961, A pollen profile from the grassland province: Science, v. 134, p. 20382040.

Sears, P. B., and Bopp, Monika, 1960, Pollen analysis of the Michillinda peat seam: Ohio Jour. Sci., v. 60, p. 149--154.

Stuiver, Minze, and Deevey, E. S., 1961, Yale natural radiocarbon measurements VI: Radiocarbon, v. 3, p. 126-140.

Tauber, Henrik, 1962, Latitudinal effect in the transport of radiocarbon from stratosphere to troposphere: Internatl. Atomic Energy Agency, Radioisotopes in the physical sciences and industry, p. 67-74.

Washburn, A. L., and Stuiver, Minze, 1962, Radiocarbon-dated postglacial delevelling in northeast Greenland and its implications: Arctic, v. 15, p. 66-73. 